\title{
Çocuklarda bel ağrısı
}

\section{Low back pain in childhood}

\author{
Tevfik Balıkçı ${ }^{1}$, Murat Bezer ${ }^{2}$ \\ ${ }^{1}$ Özel Meditime Hastanesi, Ataşehir, İstanbul \\ ${ }^{2}$ Marmara Üniversitesi Pendik Eğitim ve Araştırma Hastanesi, Pendik, İstanbul
}

\begin{abstract}
Çocuklarda ve adolesanlarda sırt ağrısının en sık görüldüģü yer, bel bölgesidir. Çocuk yaş grubunda bel ağrısı sıklığı \%9-66 arasında değişmekte olup, yeni yapılan çalışmalardaki sıklık oranları, kullanılan daha iyi yöntemler ve yeni tanımlamalar sayesinde, eski çalışmalara göre daha fazla görünmektedir. Bel ağrısının görülme sıklığı, hasta grubunun yaşına ve aktivite düzeyine göre değişir. Büyük çocuklarda ve adolesanlarda bel ağrısı prevalansının, küçük çocuklardan daha fazla olduğuna dair kanıtlar mevcuttur. Çocukluk çağı bel ağrısı yakınması, iyi bir öykü, dikkatli bir fizik muayene, gerekli durumlarda görüntüleme yöntemleri ve laboratuvar testleri kullanılarak değerlendirilmelidir.
\end{abstract}

Anahtar sözcükler: bel ağrısı; çocukluk çağı; fıtıklaşmış disk, pediatrik; tedavi
Low back pain is the most common type of back pain in children and adolescent. It has a wide range of prevalence $(9-66 \%)$ in pediatric age group, while most recent studies show a higher prevalence with respect to older studies, due to utilization of better methodology and newer definition low back pain. The prevalence depends on the age and the level of activity of the patients. There are evidences showing that the prevalence of back pain in older children and adolescents are much higher than younger. The complaint of childhood low back pain should be assessed with a thorough history, a careful physical examination, and by imaging devices and laboratory tests, if necessary.

Key words: low back pain; childhood; herniated disk, pediatric; treatment
Ç ocuklarda ve adolesanlarda sırt ağrısının en sık görüldüğü yer bel bölgesidir.. ${ }^{[1]}$ Bel ağrısı, 12. kaburganın altından başlayan ve gluteal bölgenin üstünde sonlanan ağrı olarak tanımlanabilir. ${ }^{[2]}$ Çocuk yaş grubunda bel ağrısı sıklı̆g \%9-66 arasında değişmekte olup, yeni yapılan çalışmalardaki sıklık oranları eski çalışmalara göre daha fazladır. ${ }^{[3]}$ Bel ağrısının görülme sıklığı, hasta grubunun yaşına ve aktivite düzeyine göre değişir. Büyük çocuklarda ve adolesanlarda bel ağrısı prevalansı, küçük çocuklardan daha fazladır (\%24-36 oranında). Buna ek olarak, bel ağrısı prevalansı, adolesan ve pre-adolesan atletlerde artmaktadır. Genç atletlerde bel ağrısı \%10-15 oranında görülürken, uğraşılan spor dalına bağlı olarak, oran değişir. Örneğin; futbolcu ve jimnastikçilerde bu oran $\% 85$ 'lere kadar ulaşır. ${ }^{[4]}$

Partan ve arkadaşlarının yaptığı çalışmada, erken çocukluk döneminde bel ağrısı etiyolojisinde daha çok organik nedenler izlenmekle birlikte, adolesan döneme doğru disk patolojilerinde artış olduğu bildirilmiştir. ${ }^{[5]}$
Çocuklarda bel ağrısı; enfeksiyon, mekanik nedenler, neoplazi veya inflamasyon gibi nedenlere bağlı gelişir. ${ }^{[6]}$ Obezite ve sportif aktivitelerin artması sonucu, kas iskelet sistemi kaynaklı sırt ağrıları artarken; nonorganik nedenler arasında, psikososyal problemler ve aile öyküsü sayılabilir. ${ }^{[6-8]}$ Ayrıca, uzun süre televizyon seyretmek, bilgisayar başında oturmak ve sedanter yaşam öyküsü de çocuklar arasında bel ağrısına neden olabilecek faktörler arasındadır. ${ }^{[10]}$

Bunnel, çocukluk çağında bel ağrılarını dört ana başlık altında tanımlamıştır:[11]

- Mekanik (postüral, hamstring gerginliği, paraspinal kas spazmı, sakroiliak disfonksiyon)

- Gelişimsel (Schuerman kifozu, spondilolizis, spondilolistezis)

- Inflamatuvar (osteomiyelit, apofizit, diskit, ankilozan spondilit)

- Tümör ve tümör benzeri lezyonlar (primer ve metastatik kemik tümörleri)

- İletişim adresi: Uzm. Dr. Tevfik Balıkçı, Ortopedi ve Travmatoloji Uzmanı, Özel Meditime Hastanesi, Ataşehir, İstanbul

Tel: 0532 - 5788551 e-posta: tevfikbalikci@hotmail.com

- Geliş tarihi: 17 Ağustos 2015 Kabul tarihi: 17 Ağustos 2015 
Bel ağrısı olan çocuklarda, pozitif aile öyküsü olanlar, olmayanlara göre yaklaşık olarak iki kat daha fazladır. ${ }^{[12]}$ Büyüyen çocuklardaki omurga problemlerinin tanı ve tedavisi, fizik muayenede ve görüntülemede yaşanan zorluklar nedeniyle, erişkinlere göre daha zordur. Erişkinlerde bel ağrısının en sık nedeni, \%48 ile, diskojenik temelli olanlardır. Adolesanlardaki bel ağrısının \%47'sinin nedeni spondilolizistir. Pediatrik yaş grubunda başlayan bel ağrıları, fizik muayene ile tanı konulup takip edilebilir. Bel ağrısının erken tanısını koyabilmek için, semptomlar iyi değerlendirmeli, diğer hastalıklar ekarte edilmelidir. Birkaç haftadan fazla süren semptomlar, önemli bir hastalığı işaret ediyor olabileceği gibi; yine birkaç haftalık konservatif tedavi ile geçen ağrı, non-spesifik bel ağrısına işaret edebilir.

\section{KLINIKK YAKLAŞIM}

Kü̈çük çocuklarda ağrı anamnezini almak gerçekten zordur; ancak, ailelerinden alınan anamnez ışığında tanıya gidilebilir. Illk olarak; hastanın yaşı, yapmış olduğu spor dalları, pozisyon, egzersiz çeşidi yanında, travma şekli ve travmanın nasıl olduğunu da sorgulamak gerekir. Ağrı semptomları, ağrının oluş yerine, şekline ve durumuna göre değişiklik gösterir. Ağrı nedeni iyice sorgulanmalıdır. Bunlar arasında; malignite, disk herniyasyonu ve inflamatuvar durumlar araştırılmalıdır. ${ }^{[13]}$ Kemik lezyonlarında ağrı lokalizasyonu belli iken, nöromusküler ve inflamatuvar nedenli ağrılarda bu net değildir. Bel ağrısı şikayeti olan hastalar daha çok mekanik ağrıdan söz ederken; sinir basısı nedeni ile şikayet eden hastalar daha çok bacak ağrısını öne sürerler.

Basit mekanik nedenli ağrılar, genellikle üç hafta kadar sürer. Dört haftadan fazla süren durumlarda, ciddi bir patolojiyle karşı karşıya kalma ihtimali yüksektir. Ağrının karakteri, tanı koyma açısından çok önemlidir. Gece ağrısı; inflamatuvar, onkojenik ya da enfektif nedenlere bağlı olabilir. İnflamatuvar nedenli ağrılarda semptomların aktivite ile azalması ya da sabah tutukluluğunun olması görülürken, mekanik nedenli ağrılarda semptomlar yürüme ve aktivite ile artar. Nörolojik ağrılar daha çok yanma şeklinde olur ve buna mesane ve barsak disfonksiyonu eşlik eder.

Ayak deformiteleri, intraspinal lezyonlara ya da gergin omurilik sendromu (tethered cord)'na eşlik edebilir. Bel ağrısı nedeniyle başvuran, özellikle dört yaş altındaki çocuklarda, muayene ve tanı koymada zorlanılabilir. ${ }^{[14]}$

Kilo kaybı, beklenmeyen ateş yükselmesi, iştah kaybı, bakteriyel ya da viral enfeksiyon varlığı, nörolojik defisit bulguları, dinlenme sırasında ya da uyku sonrası ağrı varlığı mutlaka sorgulanmalıdır.

\section{KLINIK MUAYENE}

İyi bir fizik muayene ile bel ağrısının diğer hastalıklardan ayrılması mümkündür. İnspeksiyonla muayeneye, çocuğun üzerindeki tüm elbiseler çıkarılıp sadece iç çamaşırı ile kalacak şekilde hazırlandıktan sonra başlanılmalıdır. Omurganın hareketleri, hasta ayakta dururken, öne ve yanlara eğilirken ve yürüme esnasında, arkadan ve yanlardan izlenmelidir. Ciltte kısmi renk değişikliği, hiperlaksite, belde yama şeklinde aşırı kıllanma ve omurga eğrilikleri göz önünde bulundurulmalıdır. Bu gibi durumların, intraspinal bir patolojiye eşlik etme ihtimali yüksektir. ${ }^{[15]}$

Dermatomlara bağlı olarak gelişmesi muhtemel olan, yansıyan ağrının tespitinde, kostovertebral açı perküsyonu ve iç organların palpasyonu muayene esasları arasındadır. Nörolojik muayene yapılırken, kasların motor kuvveti ve refleksler değerlendirilmelidir.

Tanıya yönelik olarak; Adams öne eğilme testi, düz bacak kaldırma testi, FABERE (fleksiyon, abduksiyon, eksternal rotasyon, ekstansiyon) testi ve trendelenburg testleri uygulanmalıdır. Adams öne eğilme testinde, çocuktan, önce dik durması, daha sonra ise ayak parmaklarına doğru öne eğilmesi istenir. Çocuğun skapulaları, omurlarının dizilimi ve genel pozisyonu gözlenir. Asimetri ve eğrilik görülüyorsa, ileri radyolojik ve ortopedik değerlendirme yöntemlerine başvurulur.

Düz bacak kaldırma testi (DBKT) ile, sinir kökü duyarılıı̆ı saptanabilir. DBKT'de, bacak kaldırılırken $20-70^{\circ}$ arasında belden bacağa doğru bir ağrı yayılır veya mevcut ağrı artarsa, test $(+)$ olarak kabul edilir; N.iskiadikus'ta irritasyon olduğu düşünülür. Test uygulanırken diz fleksiyona geliyor veya ağrı özellikle diz arkasında yerleşim gösteriyorsa, hamstring kısalığı; $30^{\circ}$ fleksiyondan önce ağrı olduğu gözleniyorsa, simülasyon veya geniş tabanlı bir disk varlığı düşünülmelidir. ${ }^{[16]}$

FABERE testinde, hasta sırt üstü yatar pozisyondayken, test edilen taraftaki kalçaya fleksiyon, abduksiyon, eksternal rotasyon ve dize fleksiyon yaptırılır. Bir elle karşı taraf pelvis stabilize edilirken, diğer elle test edilen tarafta kalça ekstansiyona getirilmeye zorlanır. Test edilen tarafta oluşan ağrı, kalça patolojisini; karşı tarafta veya sakroiliak eklemde meydana gelen ağrı ise sakroiliak eklem patolojisini düşündürür.

Trendelenburg testinde, çocuğun arkadan gözlenmesi gerekmektedir. Çocuktan, hiç bir yerden destek almadan tek ayak üstünde durması istenir. Gluteus medius yetersizliği olan durumlarda, çocuk tek ayak üstünde durmaya çalıştı̆̆ında, pelvis karşı tarafa doğru eğilir. Bu, kalçada abduktor kas yetersizliği olduğunu gösteren bir testtir. Çocuklarda fonksiyonel ve motor 
aktiviteler sırasında yapılacak nörolojik muayene, statik değerlendirmelere göre daha anlamlıdır. Normal yürüyüş esnasında ve ayakta dururken gözden kaçabilecek hafif sorunların, hızlı yürüme ve koşma esnasında görülebileceği unutulmamalıdır. ${ }^{[15,17]}$

\section{ÇOCUKLARDA BEL AĞRISINA NEDEN OLAN PATOLOJILER}

\section{Lomber Disk Herniyasyonu}

Disk herniyasyonu, nükleus pulpozusun annüler yaralanma sonucu epidural mesafeye doğru yer değiştirmesi ve spinal kökü sıkıştırmasıyla ortaya çıkan bel ve bacak ağrısıyla karakterizedir. Lomber disk herniyasyonu; çocuklarda ve genç erişkinlerde az rastlanılan bir durum olup, James ve arkadaşlarının yaptığı çalışmada, lomber disk herniyasyonu tanısı konulan 16 yaş altı hastaların yalnızca $\% 0,5$ 'ine cerrahi prosedür uygulanmıştır. ${ }^{[18]}$ Pediatrik popülasyonda en sık 10-18 yaş aralığında görülmekte olup, erkeklerde kızlardan daha fazla izlenir.

Disk herniyasyonunda en sık görülen bulgu, kalçanın rotasyonu ve öne fleksiyonu neticesinde beldeki ağrının şiddetlenmesidir. Hasta medikal tedavi alırken, semptomların gerilemesi bir yıla kadar sürebilir. Bazı durumlarda, kalçada, dizin posteriorunda ve hamstring kaslarında ağrı meydana gelebilir. ${ }^{[19]}$ DBKT nadiren pozitiftir. ${ }^{[20]}$ Lomber disk herniyasyonu bulunan hastaların yaklaşık yarısında, düz grafilerde herhangi bir patolojiye rastlanılmamıştır.

Groebler ve arkadaşlarının yaptığı çalışmada, en sık görülen röntgen bulgusu, hastaların \%72'sinde görülen, non-strüktürel skolyozdur. Ayrıca, hastaların $\% 71$ 'inde, herniyasyon seviyesinde asimetrik faset oryantasyonu görülmüştür. ${ }^{[21]}$ Lomber disk herniyasyonunun değerlendirilmesinde manyetik rezonans (MR) görüntüleme en iyi ve sık kullanılan tercihtir; disk içeriği ve sinir köklerinin görüntülenmesinde, diğer radyolojik yöntemlere üstünlük sağlar ve epidural abse, spinal kord tümörleri, konus medullaris ve kauda ekina gibi patolojilerin ayrılmasında yararlıdır. Konservatif tedavide; egzersiz, medikal tedavi ve istirahat önerilebilir. Konservatif tedaviden yarar görmeyen ve ilerleyici nörolojik defisiti olan hastalarda, cerrahi prosedür uygulanabilir. ${ }^{[22]}$ Yapılan çalışmaların büyük bir çoğunluğunda konservatif tedavide başarı sağlanmasına rağmen, De Luca ve arkadaşlarının yaptığı çalışmada, lomber disk hernisi tanısı nedeniyle konservatif tedavi endikasyonu konulan ve uygulanan hastaların \%75'inde başarısız sonuç alınmış olup, bu hastalara laminotomiyle beraber disk eksizyonu uygulanmıştır; bunların \%91'inde iyi ve mükemmel sonuçlar alındığı görülmüş̧tür. ${ }^{[23]}$

\section{Spondilolizis ve Spondilolistezis}

Spondilolizis, vertebranın pars interartikülaris kısmında görülen, genellikle dördüncü ve beşinci lomber omurları etkileyen, tek ya da iki taraflı bir kemik defektidir. Aynı seviyede ve iki taraflı defektlerde, tutulan vertebranın öne doğru yer değiştirmesine de spondilolistezis denir. Spondilolistezis, genellikle lizis defektinin bulunduğu vertebranın alttakine göre öne doğru kayması şeklinde gelişir. ${ }^{[24]}$ Ağrı, genellikle sinsi başlangıçı ve ilerleyicidir. Uzun süreli olarak remisyon periyodları görülür. ${ }^{[25]}$

Spondilolistezisin fizik muayenesinde, palpasyonla bölgesel ağrı bulgusu ve hamstring gerginliği görülür. Kaymanın tipine ve derecesine bağlı olarak, radiküler ağrı meydana gelebilir. Kalça fleksiyonunda kısıtlılık oluşmasıyla birlikte, ördekvari yürüyüş, adım mesafesinde azalma ve geniş tabanlı yürüme başlar. Yürüyüşteki bu kompansatuvar mekanizma, lumbosakral kifoz, lomber hiperlordoz, hamstringlerde gerginlik sonucu gelişir. ${ }^{[26]}$

Spondilolistezis için günümüzde en sık kullanılan sınıflama, Wiltse sınıflamasıdır. Wiltse sınıflamasına göre, spondilolistezis altı alt gruba ayrilır.

- Displastik (konjenital)

- İstmik

- Dejeneratif

- Post-travmatik

- Patolojik

- İyatrojenik

Displastik spondilolisteziste faset tropizmi, pars interartikülariste uzama veya bölünme görülür. Faset eklemden destek alınamaması nedeniyle, üst vertebra alt vertebra üzerinde kayar (slipping). Kadınlarda, erkeklerden yaklaşık olarak iki kat daha fazla görülür. ${ }^{[27]}$ İstmik spondilolistezis en sık görülen tiptir. Stres kırığına bağlı oluşan pars defekti, tekrarlayıcı mikro-travmalar neticesinde parsın uzaması, akut veya kronik pars kırığına bağlı meydana gelir.

Dejeneratif spondilolistezis, lomber dejenerasyona bağlı kronik instabilite sonucu oluşur. Dejeneratif spondilolistezis, genellikle 50 yaş üstü kadınlarda görülür. En sık L4-5 seviyesinde, daha sonra L3-4 ve daha da az olarak L5-S1 seviyesinde görülür. Kayma, hiçbir zaman Grade 1 ve 2 düzeyini (\%30 oranını) geçmez. Post-travmatik spondilolistezis, pars interartikülaris dışındaki posterior elemanların kırıklarına bağlı oluşur. ${ }^{[28]}$ Travmadan birkaç hafta veya ay sonra ortaya çıkar. Patolojik spondilolistezis; Paget hastalı̆̆ı, von Recklinghausen hastalığı, osteogenezis imperfekta, artrogripozis, osteopetrozis, Marfan sendromu, enfeksiyon ve tümör gibi patolojilerle, pars interartikülaris veya fasetin harabiyete uğraması ve lizise yol açması sonucu oluşur. 

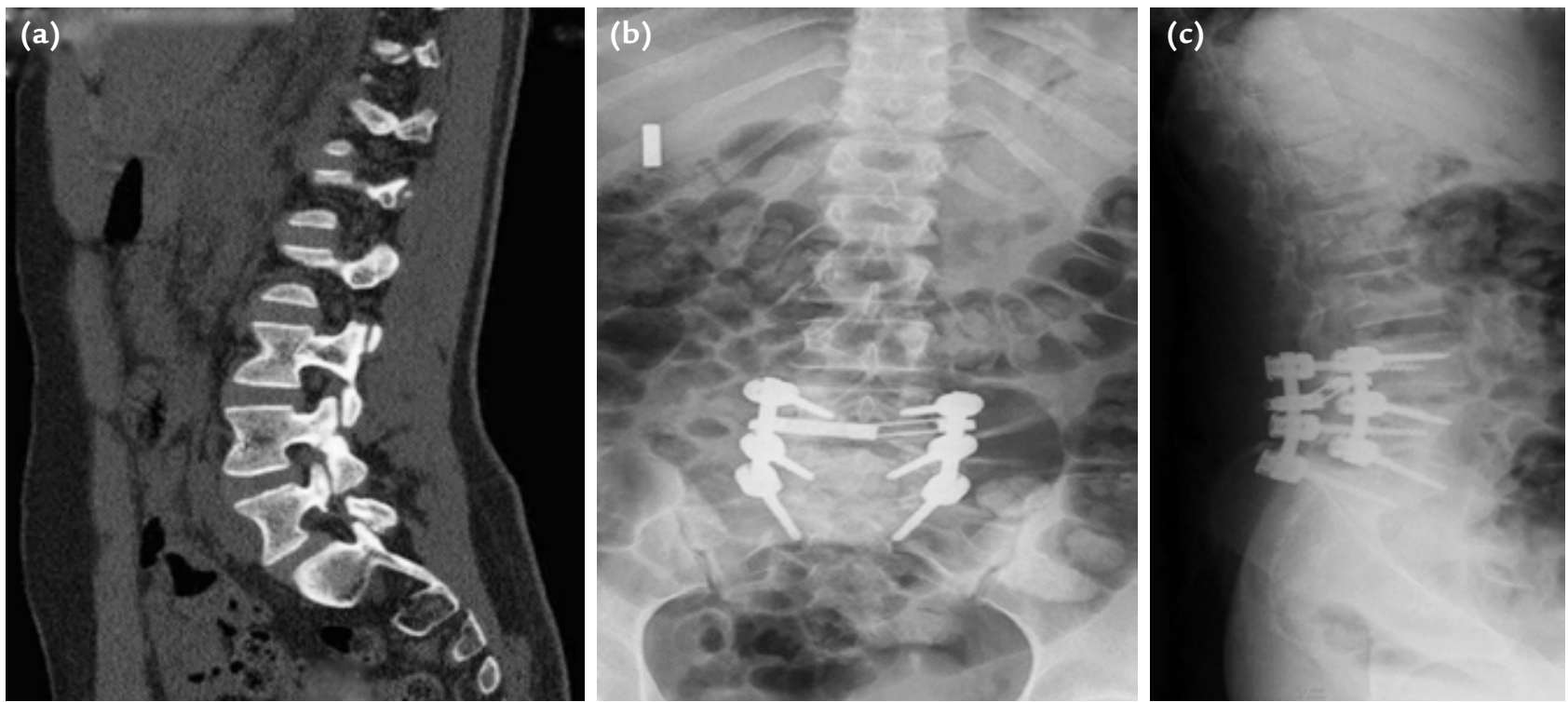

Şekil 1. a-c. On beş yaşında kız hasta, Meyerding Tip 2. Cerrahi öncesi MR (a) ve redüksiyon + posterior enstrümantasyon + füzyon uygulandıktan sonraki X-ray görüntüleri $(b, c)$.
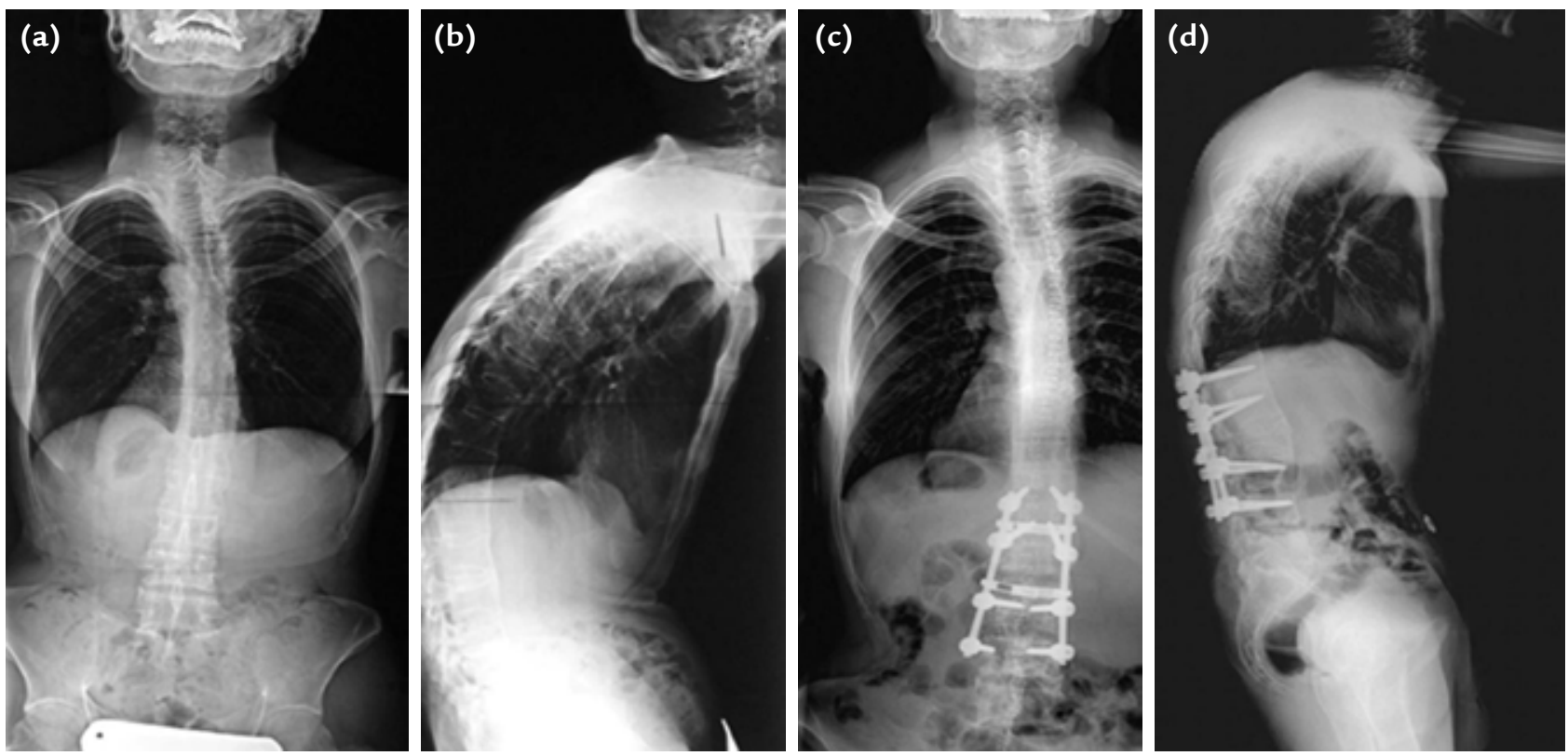

Şekil 2. a-d. Cerrahi öncesi ve sonrası görüntüler. On altı yaşındaki erkek hastaya, Schuermann kifozu nedeniyle L-2 seviyesine pedikül substraksiyon osteotomisi yapıldı. T12-L1, L3-L4 seviyesine posterior enstrümantasyon ve füzyon uygulandı.

İyatrojenik spondilolistezis, dejeneratif lomber hastalıklar neticesinde uygulanan cerrahi girişimler sonucu oluşur. Dekompresif spinal ameliyatlar sonrası instabilite gelişme oranı \%3-5'tir.

Spondilolizisin klinik tanısının doğrulanmasında, oblik ve lateral grafilerin çekilmesi gerekir. İskoç köpeği görüntüsü, spodilolizis tanısı konulan hastalarda tipik oblik düz grafi bulgusudur. Bilgisayarlı tomografi
(BT), spondilolizis tanısı koymada altın standart olsa da; çocuk ve genç erişkinlerde radyasyondan sakınmak amacıyla, son yıllarda MR görüntüleme kullanılmaya başlanmıştır. ${ }^{[20,29]}$

Nörolojik defisiti olmayan hastalarda ilk tercih, konservatif tedavidir. Meyerding ölçümlerine göre, kayma oranı \%50'nin altında olan ve fiziksel muayene bulgusu olmayan hastalarda da konservatif tedavi endikasyonu 

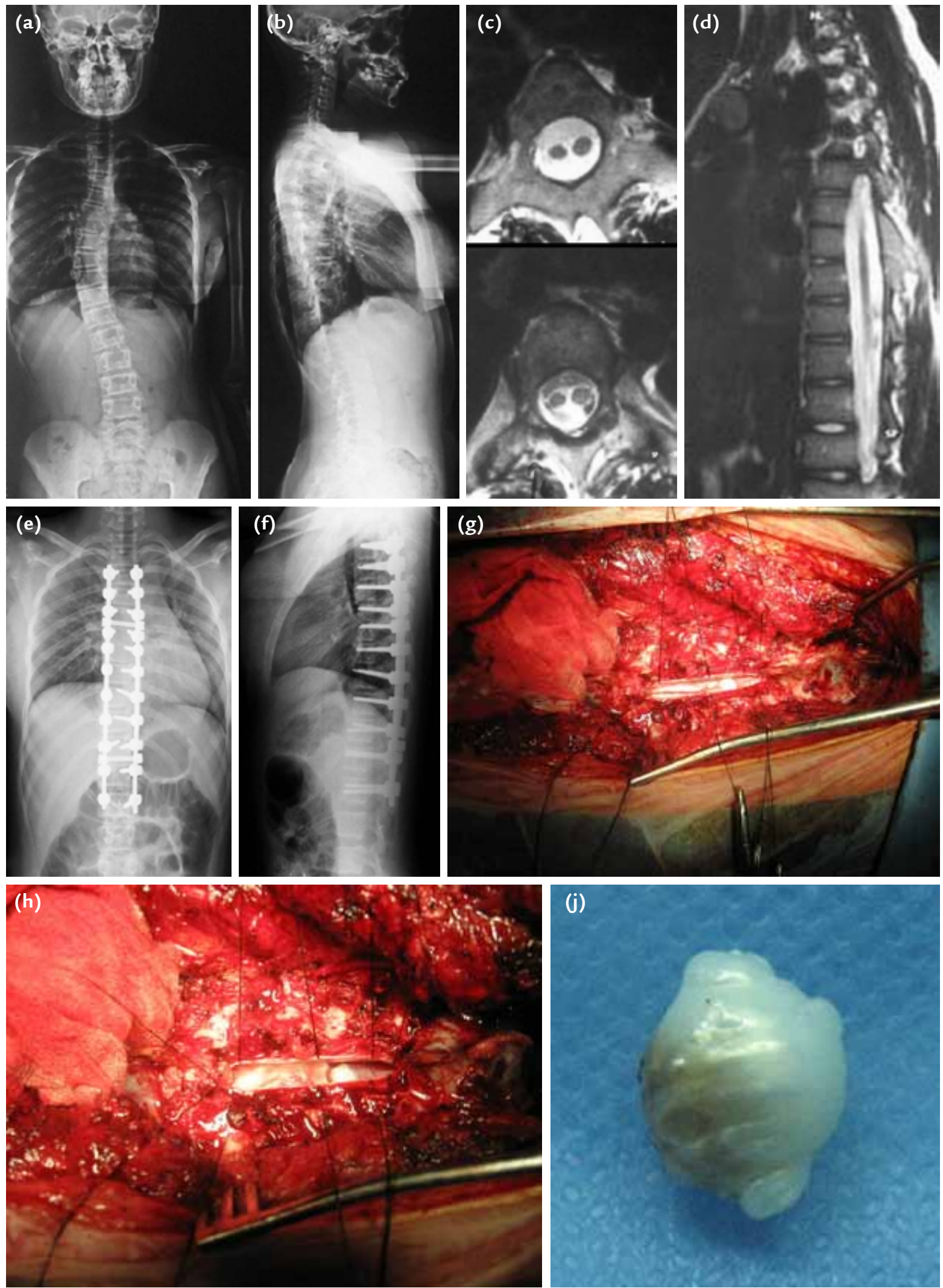

(j)

Şekil 3. a-j. On dört yaşında kız hastaya, Lenke Tip Ib idiyopatik skolyoz ve T6-T7 seviyesinde intradural kist nedeniyle kistektomi + posterior enstrümantasyon uygulandı. Cerrahi öncesi röntgen (a, b) ve MR aksiyel ve sagittal kesitleri (c, d); cerrahi sonrası röntgen görüntüleri $(e, f)$; kistin cerrahi sırasında $(g, h)$ ve cerrahi sonrası görüntüsü (j). 
bulunmaktadır. Bununla birlikte, yüksek kayma oranı görülen çocuklarda, periyodik kontrollerin dikkatli bir şekilde yapılması gerekir. Bu olgularda ilerleme gözlenebilir. ${ }^{[30]}$ Konservatif tedavi, göreceli istirahat ve ağrıyı arttıran aktivitelerin (tekrarlayıcı bel ekstansiyonları) kısıtlanması şeklindedir. Semptomatik olan hastalarda, korse kullanımı da oldukça sık kullanılan bir yöntemdir. Lomber lordozu azaltmak, hamstring kontraktürlerini önlemek ve ağrııı hafifletmek açısından, germe ve güçlendirme egzersizlerini de içeren fizik tedavi programları önerilir.

Altı ay boyunca konservatif tedaviye cevap vermeyen, spondilolitik defekti olan ve iyileşmeyen, persistan ağrı meydana getiren pars kırığı ve ilerleyici nörolojik defisit varlığında, periyodik takiplerde $\% 50$ 'den fazla kayma olduğunda, progresif duruş ve yürüme bozukluğu, düzelmeyen hamstring gerginliği, anormal veya antaljik yürüyüş meydana geldiğinde, cerrahi tedavi uygulanır. ${ }^{[19,31]}$ Cerrahi tedavide amaç; dekompresyon uygulamak, en az segmentin füzyonuyla kaymayı azaltıp, sagittal düzelmeyi sağlamaktır. ${ }^{[32]}$

\section{Schuermann Kifozu}

Schuermann kifozu, geç çocukluk ve ergenlik evrelerinde görülen bir omurga deformitesidir. İkincil ossifikasyon merkezlerinde oluşan osteokondritin sonucu olarak görülen, rijid kifozdur. Genelde alt torakal ve üst lomber bölgede görülür. Birkaç omurga segmentinin tutulumuyla sonuçlanacağı gibi, omurganın tamamında da görülebilir. ${ }^{[33]}$

Ağrı, genellikle eğriliğin apeksinde meydana gelir ve uzun süreli oturumda, ayakta kalmada ve aktivite sonrasında artar. İnspeksiyonda, torasik kifoz ve lomber lordozdaki artış göze çarpar. Hasta öne eğildiğinde, torasik kamburlukta artış gözlenir. ${ }^{[34]}$

Hasta pron pozisyonda yatarken, torasik hiperekstansiyon yaparak kifozu tam olarak düzeltemez, oldukça sabit ve rijid bir deformitesi vardır. Lomber lordozdaki artış ise genellikle kompansatuvardır ve öne eğilmekle düzelir. ${ }^{[35]}$ Düz grafilerde, üç ve daha fazla sayıda vertebrada, ardışık olarak $5^{\circ}$ 'nin üzerinde kamalaşma, sagittal planda $40^{\circ}$ 'nin üzerinde kifoz ve vertebra uç plağında düzensizlik görülür. ${ }^{[36]}$

Büyüme döneminde ve $70^{\circ}$ 'nin altında esnek eğriliklerde korse uygulanmaktadır. Korse tedavisinin, $75^{\circ}$ 'nin üzerinde başarısız olduğu gösterilmiştir. Korse olarak, Milwaukee breys veya modifiye Boston breys tercih edilmelidir. Korse uygulamasına, belirli aralıklar ile, iskelet matüritesinin tamamlanmasına kadar devam edilmelidir. ${ }^{[37]}$

İlerleyici nörolojik defisit kesin endikasyon olmakla birlikte; progresif ilerleyen eğrilikler, cerrahi dışı yöntemlerle geçmeyen ağrı, torakal bölgede $80^{\circ}$ 'nin üzerindeki eğrilikler ve torakolomber bölgede $65^{\circ}$ 'nin üzerindeki eğrilikler, göreceli cerrahi endikasyonları oluşturur. ${ }^{[33]}$ Cerrahide, anterior, posterior veya kombine yöntemler uygulanabilirse de; ayrıca, anterior gevşetme ve füzyon ile kombine edilen posterior enstrümantasyon ve füzyon uygulanabilmekle birlikte, ${ }^{[38]}$ son yıllarda, posterior kapama kama osteotomisi (Ponte osteotomisi) veya anterior açma ile posterior kolon osteotomisi (Smith-Peterson osteotomisi) ile kombine edilen posterior enstrümantasyon ve füzyon uygulaması ile, yeterli ve güvenli düzeltme sağlanabilmektedir. ${ }^{[39]}$

\section{Tümör ve Tümör Benzeri Patolojiler}

Çocukluk çağı spinal tümörlerin çoğu iyi huyludur. Osteoid osteoma ve osteoblastom en sık görülen çocukluk çağı spinal tümörleridir. ${ }^{[40]}$ Tümöre bağlı ağrı; genellikle fokaldir, gece meydana gelir, hastayı uykudan uyandırır, zaman içinde şiddetlenme gösterir ve aktiviteden bağımsız olabilir. Nörolojik bulgular seyrek olarak gözlenir.

Boriani ve arkadaşlarının yaptığı çalışmada, iyi huylu kemik tümörleri arasında, tanı konulduğunda yalnızca anevrizmal kemik kisti ve dev hücreli tümörde \%25'in üzerinde nörolojik bulgular izlendiği bildirilmiştir. ${ }^{[41]}$

Bel ağrısı nedeniyle konservatif tedaviye cevap vermeyen ve gece ağrısı olan dört yaş altı çocuklarda, kuşkucu olmak gerekir. Shives ve arkadaşları tarafından yapılan çalışmada, omurgada kötü huylu kemik tümörü veya metastatik lezyon bulunan hastaların \%70'inde nörolojik tutulum olduğu bildirilmiştir. ${ }^{[42]}$

Kötü huylu tümörlerin kemik metastazları, en sık omurgada gözlenir (\%80). Metastatik lezyonlar, sıklıkla 10 yaş altı çocuklarda görülür. ${ }^{[43]}$ Hastanın anamnezi ve fizik muayene bulguları spinal bir tümörün varlığını düşündürse de, spesifik tanı konulmasında görüntüleme yöntemleri altın standarttır. ${ }^{[4]}$

Geriye dönük olarak yapılan bir çalışmada, omurgada tümör varlığı bulunan 82 hasta incelenmiş ve bunların \%99'unda, düz grafilerde patolojik bulgular saptanmıştır. ${ }^{[45]}$ Tümöral lezyonun boyutu, karakteri, yumuşak doku yayılımı gibi özellikleri tespit edebilmek için, MR, BT ve sintigrafi gibi ileri görüntüleme yöntemleri kullanılır.

\section{Sakroiliak Eklem Ağrısı}

Sakroiliak eklem ağrısında, çoğunlukla mekanik faktörler öne çıksa da, inflamatuvar ve enfeksiyöz nedenler de düşünülmelidir. Pozitif FABERE testi ile artan bel ağrısı, mekanik bir nedene bağlı sakroiliak eklem ağrısında tipik muayene bulgularıdır. Trendelenburg testi de pozitif sonuç verebilir. ${ }^{[1]}$ Kesin tanı testi, sakroiliak 
eklem bloğu uygulanmasıdır. Bu işlem, floroskopi altında uygulanır ve uygulama sonrasında ağrı seviyesinde \%75'ten fazla düşüş̧, tanıyı doğrulatır. ${ }^{[46]}$ Ayrıca, sakroiliak eklem tutulumu ve ayırıcı tanıda, kontrastlı MR önemli bir yere sahiptir.

\section{Juvenil Primer Fibromiyalji Sendromu}

Juvenil primer fibromiyalji sendromu; etiyolojisi bilinmeyen yaygın persistan ağrı, uyku bozukluğu, yorgunluk, baş ağrısı gibi bulgular veren kronik ağrı sendromudur. ${ }^{[47]}$ Yapılan çalışmalarda, çocukluk ve ergenlik döneminde \%1-2 arasında olduğ $u^{[47,48]}$ ve kızlarda, erkeklerden daha sık görüldüğü bildirilmiştir. ${ }^{[13]}$ Tedavide multidisipliner yaklaşımlar uygulanır. Farmakolojik tedavilere ek olarak; bilişsel davranış tedavisi, hasta eğitimi, fizik tedavi ajanları ve egzersiz programlarından yararlanilır. ${ }^{[49,50]}$

\section{Enfeksiyöz Nedenler}

Omurga, fibrokartilajinöz disk ve sakroiliak eklemler, enfeksiyöz ajanlara duyarlı yapılardır. ${ }^{[13]}$ Spinal tüberküloza (Pott hastalığı) neden olan Mycobacterium tuberculosis, omurlara zarar verebileceği gibi; hematojen yolla, spinal korda, diske ve bu yapıları çevreleyen dokulara da yayılabilir. Çocuklarda, sıklıkla alt torasik ve lomber omurlar tutulum gösterir. ${ }^{\left[{ }^{[1]}\right.}$ Spinal tüberkülozda; intervertebral disk aralığında ve bitişik omur cisimlerinde erozyon ve reaktif değişiklikler, paravertebral yumuşak doku bölgelerinde kalsifikasyon, açılanmaya neden olacak şekilde anterior kamalaşma görülür. ${ }^{[52]}$ Görüntüleme yöntemleri, ayırıcı tanıya yardımcı olduğu gibi, spinal tüberkülozun yol açtığı paravertebral ve epidural abse, kifoz gibi komplikasyonların tanınmasında da kullanılır. MR görüntüleme, omurga enfeksiyonunun, özellikle Pott hastalığının tanısında en güvenilir görüntüleme yöntemidir. ${ }^{[13]}$

Spondilodiskit; her yaş grubunda görülebilen, son bir kaç ay içerinde geçirilmiş bakteriyel veya viral bir enfeksiyonu takip eden bir süreçte meydana gelebilen, sıklıkla intervertebral disk aralığı, alt ve üst vertebra platolarında yerleşen inflamatuvar bir patolojidir. Spencer ve arkadaşları, bel ağrısı şikayetiyle başvuran 520 çocuğu incelemişler; 12 çocukta $(\% 2,3)$ spondilodiskit tanısı koymuşlardır. ${ }^{[53]}$ Spondilodiskitte, özellikle alt torasik ve lomber vertebralar etkilenmektedir. $L 5$ ve S1, en çok etkilenen omurlardır. ${ }^{[54]}$ Alınan kan kültürlerinde çoğunlukla üreme görülmezken, Staphylococcus aureus en sık izole edilen organizmadır. Semptomlar görüldükten sonraki üç hafta içerisinde, çoğunlukla radyolojik bulguya rastlanmaz. Illerleyen dönemlerde, tutulan omur seviyesinde disk yüksekliğinde azalma, end plate seviyesinde skleroz ve erozyon görülür.
Spondilodiskitten şüphe edildiği durumlarda, tam kan sayımı ve sedimantasyon değerleri ölçülmelidir. Omurgada piyojenik enfeksiyon tanısı konulan hastaların \%90'ında, sedimantasyon değerleri yüksek bulunmuştur. Yüksek sedimantasyon ve normal düz grafi bulgularında, ileri tetkik ve ayırıc tanı amacıyla, MR görüntüleme ve sintigrafiden yararlanılır. MR görüntüleme ile, spondilodiskitin osteomiyelitten, epidural abseden ve spinal tüberkülozdan ayrılması sağlanır. Spinal tüberkülozun MR incelemesinde, sıklıkla disk mesafesinde sinyal değişikliğine rastlanmaz. Epidural abse varlığında, bel ağrısına sıklıkla ateş eşlik eder. Ayrıca, reflekslerde azalma, kök iritasyonu bulguları ve kas güçsüzlüğü görülebilir. ${ }^{[55]}$

\section{SONUÇ}

Bel ağrısı, çocukluk çağında oldukça sık karşılaşılan bir sorundur. Çocuklarda görülen bel ağrısını büyümeye bağlı kemik ağrısı olarak görmek, tehlikeli sonuçlara yol açabilmektedir. Bu nedenle, çocuklarda bel ağrısı ciddiye alınmalı, ayrıntılı anamnez ve fizik muayene ile çocukların şikayetleri değerlendirilmelidir. Tanı amacıyla uygulanan yardımcı görüntüleme yöntemleri ve laboratuvar testleri, hekimin doğru ve güvenli tanı koymasında yararlı olacaktır.

\section{KAYNAKLAR}

1. Kordi R, Rostami M. Low back pain in children and adolescents: an algorithmic clinical approach. Iran J Pediatr 2011;21(3):259-70.

2. Andersson JA. Problems of classification of low back pain. Rheumatol Rehabil 1977;16(1):34-6.

3. Calvo-Muñoz I, Gómez-Conesa A, Sánchez-MecaJ. Prevalence of low back pain in children and adolescents: a meta-analysis. BMC Pediatr 2013;13:14. CrossRef

4. De Luigi AJ. Low back pain in the adolescent athlete. Phys Med Rehabil Clin N Am 2014;25(4):763-88. CrossRef

5. Partan G, Eyb R, Artacker G. Imaging of non-traumatic spinal diseases in children. Radiologe 2010;50(12):1107-14. CrossRef

6. Haus BM, Micheli LJ. Back pain in the pediatric and adolescent athlete. Clin Sports Med 2012;31(3):423-40. CrossRef

7. Smith SM, Sumar B, Dixon KA. Musculoskeletal pain in overweight and obese children. Int J Obes (Lond) 2014;38(1):11-5. CrossRef

8. Jones GT, Watson KD, Silman AJ, Symmons DP, Macfarlane G). Predictors of low back pain in British schoolchildren: a population-based prospective cohort study. Pediatrics 2003;111(4 Pt 1):822-8.

9. Lynch AM, Kashikar-Zuck S, Goldschneider KR, Jones BA. Psychosocial risks for disability in children with chronic back pain. J Pain 2006;7(4):244-51.

10. Davis PJ, Williams HJ. The investigation and management of back pain in children. Arch Dis Child Educ Pract Ed 2008;93(3):73-83. CrossRef 
11. Bunnell WP. Back pain in children. Orthop Clin North Am 1982;13(3):587-604.

12. Hestbaek L, Leboeuf-Yde C, Kyvik KO, Manniche C. The course of low back pain from adolescence to adulthood: eight-year follow-up of 9600 twins. Spine (Phila Pa 1976) 2006;31(4):468-72.

13. Taxter AJ, Chauvin NA, Weiss PF. Diagnosis and treatment of low back pain in the pediatric population. Phys Sportsmed 2014;42(1):94-104. CrossRef

14. Jackson C, McLaughlin K, Teti B. Back pain inchildren: a holistic approach to diagnosis and management. J Pediatr Health Care 2011;25(5):284-93. CrossRef

15. Cassidy JT. Musculosceletal pain syndromes of nonrheumatic origin. In: Cassidy JT, Petty RE, editors. Textbook of pediatric rheumatology, 3rd ed. Philadelphia, PA, USA: W.B. Saunders Company; 1995. p.108-32.

16. Borenstein DG, Wiesel SW, Boden SD, editors. Low Back Pain, Medical Diagnosis and Comprehensive Management, 2nd ed. Philadelphia: WB Saunders Co.; 1995. p.63-182, 595-650.

17. Sills JA. Non-inflammatory musculoskeletal disorders in childhood. Arch Dis Child 1997;77(1):71-5.

18. Lawrence JP, Greene HS, Grauer JN. Back pain in athletes. J Am Acad Orthop Surg 2006;14(13):726-35.

19. Ginsburg GM, Bassett GS. Back Pain in Children and Adolescents: Evaluation and Differential Diagnosis. J Am Acad Orthop Surg 1997;5(2):67-78.

20. Rodriguez DP, Poussaint TY. Imaging of back pain in children. AJNR Am J Neuroradiol 2010;31(5):787-802. CrossRef

21. Grobler LJ, Simmons EH, Barrington TW. Intervertebral disc herniation in the adolescent. Spine (Phila Pa 1976) 1979;4(3):267-78.

22. Fakouri B, Nnadi C, Boszczyk B, Kunsky A, Cacciola F. When is the appropriate time for surgical intervention of the herniated lumbar disc in the adolescent? J Clin Neurosci 2009;16(9):1153-6. CrossRef

23. DeLuca PF, Mason DE, Weiand R, Howard R, Bassett GS. Excision of herniated nucleus pulposus in children and adolescents. J Pediatr Orthop 1994;14(3):318-22.

24. d'Hemecourt P, Gerbino PG 2nd, Micheli LJ. Back injuries in the young athlete. Clin Sports Med 2000;19(4):663-79.

25. Erdine $S$, Tolunay $M$. Ağrının değerlendirilmesi ve ağrı ölçümleri. İçinde: Erdine S, editör. Ağrı. İstanbul: Nobel; 2000. p.91-107.

26. Grobler LJ, Robertson PA, Novotny JE, Pope MH. Etiology of spondylolisthesis. Assessment of the role played by lumbar facet joint morphology. Spine (Phila Pa 1976) 1993;18(1):80-91.

27. Amundson G, Edwards CC, Garfin RS. Spondylolistezis. In: Rothman RH, Simone FA, editors. The Spine, 3th edition, Philadelphia: WB Saunders Co.; 1992. p.913-69.

28. Boldwin NG, Ebni BL. Spondilolisthezis; Sagital Plane Lumbar Spine Deformity Correction. In: Benzel E, editor. Spine Surgery. Techniques, Complication Avoidance and Management. Philadelphia: Churchill Livingstone; 1999. p.435-47.

29. Jackson C, McLaughlin K, Teti B. Back pain in children: a holistic approach to diagnosis and management. J Pediatr Health Care 2011;25(5):284-93. CrossRef

30. Wiltse LL, Spencer CW. New uses and refinements of the paraspinal approach to the lumbar spine. Spine (Phila $\mathrm{Pa}$ 1976) 1988;13(6):696-706.
31. Turner R, Bianco A Jr. Spondylolysis and spondylolisthezis in children and teen-agers. J Bone Joint Surg Am 1971;53:1298-306.

32. Zileli M, Kepoğlu Ü. Lomber spondilolistezis, Spondilolistezis, Omurilik cerrahisi. İçinde: Zileli M, Özer F, editörler. Omurilik ve omurga cerrahisi, 1. Cilt. 2. baskı. İzmir: Meta; 2002. p.769-82.

33. Yaman O, Dalbayrak S. Kifoz: Tanı, Gruplama ve Tedavi Yöntemleri. Türk Nöroşirürji Dergisi 2013;23(Suppl 2):61-73.

34. Bradford DS. Juvenile Kyphosis. In: Lonstein JE, Bradford DS, Winter RB, Ogilvie JW, editors. Moe's Text book of Scoliosis and Other Spinal Deformities, 3rd ed. Philadelphia PA: W.B. Saunders; 1995. p.349-67.

35. Lowe TG. Scheuermann's disease. In: Bridwell HB, DeWald $\mathrm{RL}$, editors. The Text book of Spinal Surgery, 2nd ed. Philadelphia: Lippincott-Raven Publishers; 1997. p.1173-98.

36. Tsirikos Al, Jain AK. Scheuermann's kyphosis; current controversies. J Bone Joint Surg Br 2011;93(7):857-64. CrossRef

37. Murray PM, Weinstein SL, Spratt KF. The natural history and long-term follow-up of Scheuermann kyphosis. J Bone Joint Surg Am 1993;75(2):236-48.

38. Aydıngöz Ö. Adolesanda Omurga Sorunları. İ. Ü. Cerrahpaşa Tıp Fakültesi, Sürekli Tıp Eğitimi Etkinlikleri, Adolesan Sağlı̆̆ı Sempozyum Dizisi 2005;43:125-33.

39. Bridwell $\mathrm{KH}$. Osteotomies for fixed deformities in the thoracic and lumbar spine. In: Bridwell KH, DeWald RL, editors. The Textbook of Spinal Surgery, 2nd ed. Philadelphia: LippincottRaven; 1997. p.821-35.

40. Delamarter RB, Sachs BL, Thompson GH, Bohlman HH, Makley JT, Carter JR. Primary neoplasms of the thoracic and lumbar spine. An analysis of 29 consecutive cases. Clin Orthop Relat Res 1990;(256):87-100.

41. Boriani S, Biagini R, Laus $M$, de lure $F$, Campanacci $L$. Giant cell tumor of the vertebral column. Chir Organi Mov 1996;81(3):233-45.

42. Shives TC, Dahlin DC, Sim FH, Pritchard DJ, Earle JD. Osteosarcoma of the spine. J Bone Joint Surg Am 1986;68(5):660-8.

43. Leeson MC, MakleyJT, CarterJR. Metastatic skeletal disease in the pediatric population. J Pediatr Orthop 1985;5(3):261-7.

44. Garg S, Dormans JP. Tumors and tumor-like conditions of the spine in children. J Am Acad Orthop Surg 2005;13(6):372-81.

45. Weinstein JN, McLain RF. Primary tumors of the spine. Spine (Phila Pa 1976) 1987;12(9):843-51.

46. Dreyfuss P, Dreyer SJ, Cole A, Mayo K. Sacroiliac joint pain. J Am Acad Orthop Surg 2004;12(4):255-65.

47. Buskila D, Press J, Gedalia A, Klein M, Neumann L, Boehm R, Sukenik S. Assessment of nonarticular tenderness and prevalence of fibromyalgia in children. J Rheumatol 1993;20(2):368-70.

48. Weir PT, Harlan GA, Nkoy FL, Jones SS, Hegmann KT, Gren $\mathrm{LH}$, Lyon JL. The incidence of fibromyalgia and its associated comorbidities: a population-based retrospective cohort study based on International Classification of Diseases, 9th Revision codes. J Clin Rheumatol 2006;12(3):124-8.

49. Anthony KK, Schanberg LE. Juvenile primary fibromyalgia syndrome. Curr Rheumatol Rep 2001;3(2):165-71.

50. Yunus MB, Masi AT. Juvenile primary fibromyalgia syndrome. A clinical study of thirty-three patients and matched normal controls. Arthritis Rheum 1985;28(2):138-45.

51. Eisen S, Honywood L, Shingadia D, Novelli V. Spinal tuberculosis in children. Arch Dis Child 2012;97(8):724-9. CrossRef 
52. Garg RK, Somvanshi DS. Spinal tuberculosis: A review. J Spinal Cord Med 2011;34(5):440-54. CrossRef

53. Spencer SJ, Wilson NI. Childhood discitis in a regional children's hospital. J Pediatr Orthop B 2012;21(3):264-8. CrossRef
54. Chandrasenan J, Klezl Z, Bommireddy R, Calthorpe D. Spondylodiscitis in children: a retrospective series. J Bone Joint Surg Br 2011;93(8):1122-5. CrossRef

55. Jacobsen FS, Sullivan B. Spinal epidural abscesses in children. Orthopedics 1994;17(12):1131-8. 